\title{
Afinidades de espírito Harold Pinter e a tragédia grega
} Frank Gillen

Para Harold

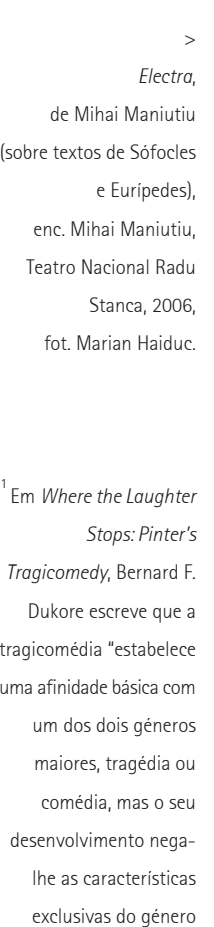
trágico ou cómico com as quais é primordialmente associada - caracteristicas do enredo, reacção do público ou ambas - e a

sua conclusão nega a exclusividade do tipo de alteração associado ao género" (1976: 3). Pinter

considerou a peça

0 encarregado (The

Caretaker) "engraçada ate um certo ponto. Para lá desse ponto deixa de se engraçada, e foi por causa desse ponto que a escrevi" (Sunday Times, Londres,

14 de Agosto de 1960). Aqui o meu argumento não é que as peças $d$ Pinter sejam "tragédia",

mas apenas que têm algumas afinidades com

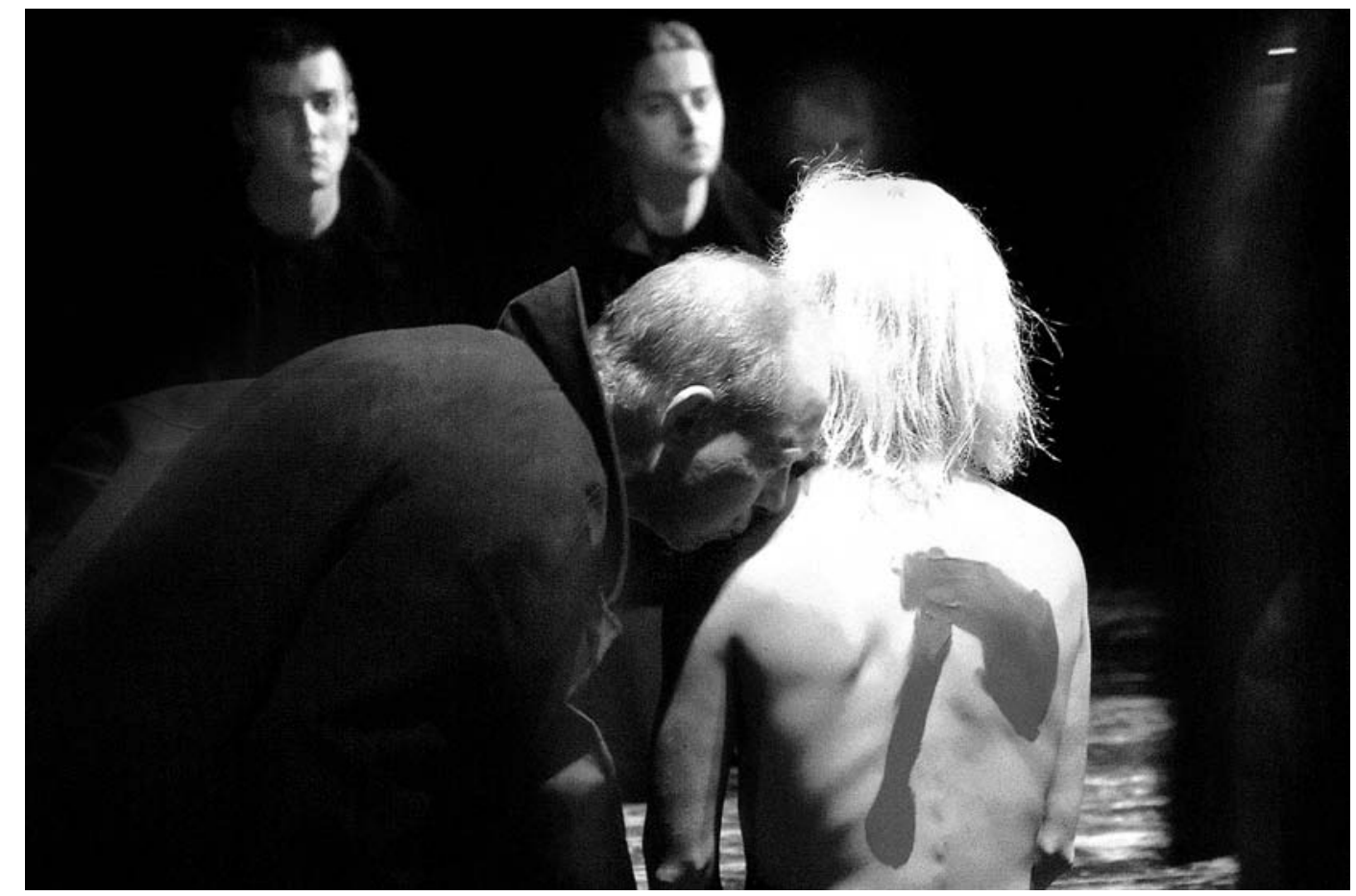

A atribuição tanto do Prémio Nobel da Literatura como do Prémio Europeu de Teatro parece-me uma boa ocasião para comparar Harold Pinter com os dramaturgos atenienses do séc. $V$ a.C. Historicamente a comparação é também pertinente, porque Atenas era nessa altura uma super potência cuja hybris a levou a declarar - aos povos de Melos antes de os destruir (a eles e, como alguns diriam, à sua própria alma) -, que os fortes fazem o que querem e os fracos têm de se submeter. Então, como agora, havia os adeptos da guerra, e havia dramaturgos que apelavam à sanidade, à paz e à sobrevivência.

Obviamente que o teatro de Pinter não é trágico no sentido de uma peça que termina com a morte da personagem principal, ou de que não esteja misturado com o riso. Alguns comentadores chamaram-Ihe "tragicómico", no sentido que Ihe confere Dürrenmatt: o de que ninguém na nossa cultura se pode erguer à estatura do trágico. E, de facto, as personagens de Pinter são muitas vezes vagabundos, loucos, amantes inconstantes, poetas de fim de semana, proxenetas, pugilistas falhados, pais e maridos semi-dementes, ou então delegados de organizações sedentos de poder mas, em última análise, impotentes - às vezes criminosos por conta própria, outras enviados oficiais, e cada vez mais criminosos autorizados pelo Estado ${ }^{1}$. A minha modesta intenção aqui não é catalogar - a obra de Pinter sempre o impede -, mas simplesmente afirmar que, vendo a sua obra em cena, se pudéssemos imaginar que seria na Acrópole em Atenas, os tragediógrafos gregos e o público, por igual, reconheceriam em Harold Pinter um espírito próximo em pelo menos dois aspectos que são tão importantes para nós hoje como o foram outrora em Atenas: primeiro, a força destrutiva da hybris, o orgulho desmesurado, $e_{\text {, }}$ depois, a consequente necessidade implícita de andar humildemente entre humanos num mundo que, em última análise, é misterioso e está para lá da ilusão de um total controlo humano. Gilbert Murray falou da hybris como "o facto de a vontade do homem desejar mais do que o seu poder logra alcançar" (1966: 226). Nisto, Pinter está mais próximo de Ésquilo e Sófocles. A Eurípedes liga-se pelo ataque que este lança, de forma consistente, aos mitos dominantes do seu tempo: a guerra justificada pelos deuses, o auto-engrandecimento, o Estado todo-poderoso, bem como a posição subserviente das mulheres. Mais do que tudo, na sua luta contra o uso do mito para absolver, tanto os indivíduos como as nações, da responsabilidade e da culpa, e o fracasso do poder que não tem discernimento. 
Ésquilo é o que parece mais longe do nosso mundo e do nosso tempo. No seu Agamémnon, o herói desse nome regressa orgulhoso da Guerra de Tróia, e, todavia, fá-lo de encontro a um ethos moral dominante que condena essa hybris. Como o Coro diz:

[A]queles que fazem correr sangue nunca escapam aos olhares dos deuses. Um dia virá, no curso das vicissitudes que consomem a nossa vida, em que as negras Erynias destruirão o homem feliz que menosprezou a justiça, e não há qualquer apelo para aquele que elas fazem desaparecer. Um nome altamente ilustre expõe-se a muitos perigos, porque é sobre os notáveis que cai o dardo de Zeus. (Ésquilo 1975: 150-151)

Agamémnon é descrito como estando vestido de metal; os exércitos tremiam perante a sua raiva. Choque e pavor. Com uma ironia terrivel, que o público percebia porque conhecia a história, Clitemnestra, depois de referir-se aos muitos boatos - que corriam enquanto estivera ausente - sobre as feridas dele e a morte que sofrera, proclama: "Para mim as fontes jorradoras de lágrimas secaram; não Ihes resta uma gota" (Ibidem: 160). Com ironia ela pede então: "E agora, cabeça querida, desce do carro sem que poises no chão, ó rei, esses pés que subverteram llion" (Ibidem). Contudo, como Harold Pinter declarou de forma tão eloquente no discurso do Prémio Nobel, uma coisa é verdade e a verdade aqui, então como agora, é que o sangue provoca sangue. E aqui o sangue de Ifigénia, a filha de Agamémnon, que ele verteu, espera pelo seu sangue dentro de casa, como, e é o Coro que o diz no início da peça: "Zeus pretende (...) que Danaios e Troianos se defrontem em lutas sem fim (...). Hoje, qualquer que seja o curso dos acontecimentos, o resultado final está fixado pelo destino" (Ibidem: 142). Como isto está próximo do tom do poema recente de Pinter, "Encontro": "Nas horas mortas da noite / Os que há muito estão mortos olham para / Os novos mortos / Que avançam até eles" (2006: 280).

De facto, ao lermos Agamémnon, descobrimos uma outra afinidade que Harold Pinter tem com Ésquilo: ambos reconhecem que o passado existe no presente não simplesmente como recordação, mas como factor de divisão, uma vez que é visto de formas diferentes. Em Agamémnon, Clitemnestra e Agamémnon, tal como as personagens de Pinter em Há tanto tempo (Old Times), por exemplo, habitam presentes diferentes porque estão a viver passados diferentes - ele de um dever cumprido em nome de Deus e do país, ela do sangue de uma filha que toca em todos os momentos do presente. Seguindo o dever para com o Estado, Agamémnon lembra-se de si próprio, para usar algumas das palavras e frases das peças políticas de Pinter, como "limpo", "puro", o criador de uma necessária "paz de aço", Clitemnestra e o Coro lembram-no como estando coberto com o sangue de Ifigénia e de todos os que morreram.

E aquele passado é todo o acto, todas as palavras até ao momento da morte de Agamémnon. Aqui penso também na peça de Pinter Cinza às cinzas (Ashes to Ashes) em que o elevado estado de consciência de Rebecca, apesar de ser provocado, traz consigo a atrocidade do passado e do presente, campos de morte nazis e Dorset, na Inglaterra: em qualquer sítio, em todos os sítios, se beija o punho do poder, ou se arranca uma criança dos braços de uma mãe. E aquele acto para Rebecca, enquanto a luz vai caindo e a paisagem da peça se torna claramente interior, não é remota nem passada, mas aqui e agora. Toda a história de Ésquilo a Pinter, como Borges escreveu, é um só acto: a criança tirada da mãe, no que Mark Batty tão certeiramente descreve como "o nosso impulso primordial de atingir uma auto-definição através da 'posse' de um outro" (2001: 55).

Quando passamos para Sófocles, pensamos obviamente em Édipo, certo na sua pureza auto-contida de que a maldição que lança sobre o assassino de Laio não o afecta, no seu desprezo para com os que discutem com ele, na troça de Jocasta relativamente aos oráculos - tudo antes de saberem a verdade. Pensamos em Creonte que, no seu orgulho de poder, declarou ao seu filho Hemon com a arrogância do tirano: "E a cidade é que vai prescreverme o que devo ordenar?" (Sófocles 2003: 338); ao que o seu filho responde: "Mandarias muito bem sozinho numa terra que fosse deserta" (Ibidem: 339). É um Creonte que só consegue ver um adversário como inumano, como o "outro". É uma Antígona que reconhece a mesma humanidade em todos, um irmão que é mais do que inimigo, um outro morto que deve ser enterrado com o respeito devido a todas as pessoas que partilham um destino comum. Sete séculos mais tarde, no poema "Morte", Harold Pinter escreve com palavras reminiscentes de Antígona:

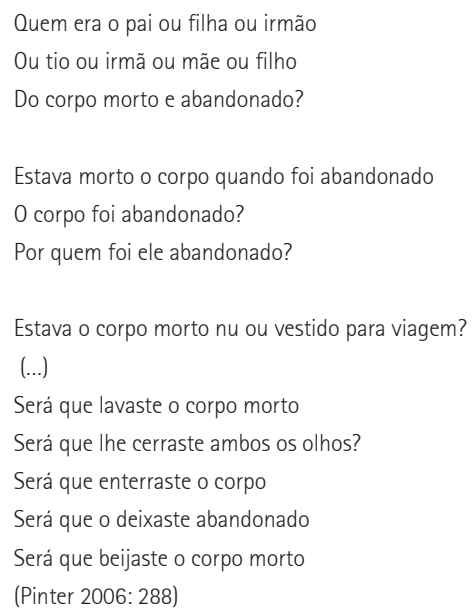

Em vez disso, na sua hybris, Creonte prepara para a sua inimiga, Antígona, uma caverna escavada na rocha e selada, que também será o lugar da morte do seu filho, a causa da morte da sua mulher, e, na sequência disso, a de a sua própria vida se ensombrar, como diz: "sobre mim impende um futuro que não se suporta" (Sófocles 2003: 363). Como o Coro declara nas palavras finais da peça: "Dos insolentes
0 especialista em estudos clássicos H. D. F. Kitto usa o termo tragicomédia para descrever as peças de Euripedes Helena e Ifigénia em Aulis. Argumenta que as peças só têm uma "realidade teatral" e, portanto, as emoções do público estão limitadas à peça e ao momento em vez de se reportarem a uma realidade externa, como na tragédia grega (1963: 203). 
sessenta e oito

Sinais de cena 6. 2006

Estudos aplicados

Frank Gillen

Afinidades de espirito: Harold Pinter e a tragédia grega
Electro

de Mihai Maniutiu

sobre textos de Sófocles

e Euripedes)

enc. Mihai Maniutiu,

Teatro Nacional Radu

Stanca, 2006,

fot. Marian Haiduc.

palavras infladas / pagam a pena dos grandes castigos" (Ibidem: 364$)$.

Embora o mundo de Pinter não seja povoado por reis, é evidente que pondera as questões da hybris e do poder. Em Feliz aniversário (The Birthday Party), Goldberg parece ter todo o poder para lidar com Stanley; todavia, na cena com que abre 0 acto III, vemos que o seu suposto poder é uma falsificação que ele não consegue interiorizar, apenas coisas soltas de uma cultura cujas palavras absorveu, mas cujo sentido e coerência, se é que existem, Ihe escapam de todo:

Assim é que eu cheguei ao que sou hoje, McCann, mantendo-me sempre em forma. Toda a vida tenho dito: é preciso estar à altura das circunstâncias. Honrar Pai e Mãe. Cortar a direito, McCann, sempre a direito. Seguindo a direito, não há que errar. Tu julgas que eu sou um homem que se fez a si próprio, não julgas? Estás muito enganado estive sempre pronto a receber lições. Sempre com atenção ao jogo. Escola? Nem é bom falar: o melhor em todas as disciplinas. E porquê? Por isso mesmo que te estou a dizer. Compreendes? Estás a seguir o

Nos silêncios de Pinter há a pura fragmentação do significado coerente - o poder sem a sageza que os gregos tanto admiravam.

De modo semelhante, em 0 encarregado (The Caretaker), no momento em que Davies se sente seguro na sua suposta aliança com um Mick escorregadio e evasivo, ele excede-se e destrói o seu lugar seguro com Aston, 0 seu irmão benevolente:

Davies tira-Ihe o saco e empurra para baixo o que está lá dentro. Tudo bem... ofereceram-me um emprego aqui... espera... (Veste o seu casaco de trazer por casa.)... espera... o teu irmão... ele vai pôr-te na ordem... chamar-me isso... chamar-me isso... nunca ninguém me tinha chamado isso... (Veste o seu sobretudo.) Vais-te arrepender de me teres chamado isso... isto não acaba aqui... (Pega no seu saco e vai até à porta.) Vais-te arrepender de me chamares isso...

Abre a porta, Aston a observá-lo.

Agora sei em que é que posso confiar. (Pinter 2002: 200-201)
0 que se segue é a sua expulsão, a perda de qualquer segurança e abrigo que pudesse ter tido. De igual modo em 0 regresso a casa (The Homecoming), no preciso momento em que o sentido de posse e autoridade masculinos parecem triunfar com toda a segurança, Ruth abala o influente poder patriarcal com as suas exigências:

RUTH: Quantos quartos é que o apartamento teria?

LENNY: Não muitos.

RUTH: Eu queria pelo menos três quartos e uma casa de banho. (...) LENNY: Dois chegavam.
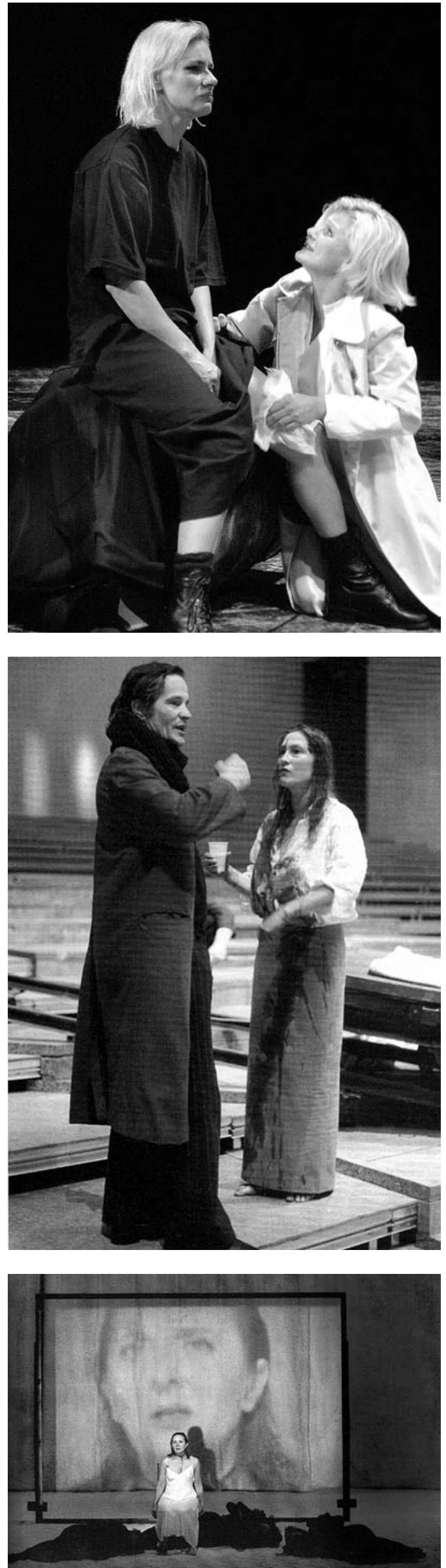
RUTH: Não. Dois não chegavam.

Pausa.

Eu queria um quarto para me vestir, um quarto para descansar, e um quarto para dormir. (Pinter 2002: 333-334)

A estas, Ruth acrescenta uma criada pessoal, financiamento a fundo perdido para as primeiras despesas, e um guardaroupa: "RUTH: Eu preciso de muita coisa. Senão não ficaria satisfeita" (Ibidem 2002: 334). No fim da peça Ruth já ocupou a cadeira de Max, Joey ficou reduzido a uma criança com a cabeça no seu colo, Teddy regressou a uma vida que promete apenas uma esterilidade crescente, e sem a paixão da anima, um afastamento maior da vida, Lenny olha sem perceber nada enquanto Max intui: "Ouve. Tenho uma impressão esquisita de que ela vai fazer merda connosco, queres apostar? Ela vai usar-nos, vai fazer uso de nós, estou-te a dizer! Consigo cheirá-lo! Queres apostar? (Pausa.) Ela não... se vai adaptar!" (Ibidem: 337-338). Cai de joelhos, o seu corpo verga-se, depois levanta a cabeça para ela e, declarando que não é um velho, pede-lhe que o beije. Exactamente o contrário do início da peça.

Claro que há diferenças. Desde logo no tom. Em Ésquilo e Sófocles, as personagens colidem com leis eternas que, na sua hybris, julgam que temporariamente não se lhes aplicam: a santidade dos laços familiares, a violência que gera violência, o mistério do destino, uma ideia de humanidade que em Antígona tão claramente vai para lá do partido, ou do Estado. Em Pinter, como alguns disseram, tudo está sujeito a negociação e é sobre isso que são as peças. Ou talvez não. Ou, pelo menos, não exactamente.

Negociações, com toda a certeza. Conflitos de perspectivas, com toda a certeza, mas aquilo que não é de facto negociável em Pinter é o mistério, poder-se-ia mesmo dizer o aspecto sagrado, da pessoa humana. A reivindicação que todo o teatro de Pinter faz dos direitos humanos começa nisto, o que há de único em todos os indivíduos - o mistério de Stanley que não se "encaixa" no mundo de Meg nem naquele para onde está a ser levado, Stanley que mostrou uma capacidade de resistência suficiente para que o público espere que, apesar de parecer derrotado agora, ele possa ainda de algum modo dar corpo às palavras de Pete: "Reaja, Stanley. Eles não têm nada que Ihe dar ordens" (Ibidem 2002: 197); o mistério do tranquilo Aston, que dá corpo a tanto sofrimento nos seus silêncios; de Ruth, que escapa a todas as tentativas patriarcais para a definirem a partir de fora. Há uma terrivel solidão no mundo teatral de Pinter que a crítica inicialmente definiu como ameaça, precisamente porque a definição de cada um, o carácter único de cada um, tem de ser constantemente reafirmado e mantido contra todos aqueles que o querem definir a partir de fora. Mas eu creio que para Pinter esta luta, a manutenção do mistério do nosso ser, é a verdadeira essência da vida. Uma forma de olhar para o teatro de Pinter é a de o ver como um ritual da vida em processo²:

Além disso, através da sua dramaturgia Pinter põe em destaque este mistério. Reside nos seus famosos silêncios, no facto de que não sabemos nada das suas personagens antes de entrarem em cena, nem depois de sairem. As suas peças não nos dão nenhumas certezas, muitas vezes nem sequer um final convencional. Resumindo, como no teatro grego, elas celebram à nossa frente o mistério de ser humano mesmo quando frustram os nossos ilusórios desejos de certezas, abstracções e controlo.

Mas entre os tragediógrafos gregos, é com o teatro de Euripedes que Harold Pinter tem mais afinidades. Em A vida da Grécia, Will Durant descreve-o como "o filho dos Sofistas, o poeta das Luzes, o representante da geração mais jovem e radical que ria dos velhos mitos, namoriscava com o socialismo, e exigia uma nova ordem social em que deveria haver menos exploração do homem pelo homem, das mulheres pelos homens, e acima de tudo pelo Estado" (Durant 1939: 413), o que não deixa de ser uma descrição genérica e nada incorrecta também de Harold Pinter. Para Euripides, os mitos do seu tempo sobre deuses, mulheres e o Estado eram usados para justificar uma flagrante imoralidade: "Esta terra de assassinos tem dado aos deuses / a sua própria volúpia" (apud Durant 1939: 413). Se acrescentarmos "ao petróleo e ao poder" àquele último verso teremos a situação de hoje.

E, no meio da guerra e todo o seu apelo, como refere Durant, "à beligerência patriótica, Euripedes mostra os horrores da guerra": "Louco entre os mortais é aquele que arrasar cidades, templos e túmulos, lugares sagrados dos que já partiram. Quem os devastar, mais tarde há-de perecer por sua vez" (Euripides 1996: 32). 0 reconhecimento de uma humanidade comum, que nasce e morre, desmistifica a guerra para Eurípedes e Harold Pinter.

Helena, de Euripedes, tem uma estranha semelhança com o nosso tempo. Nessa peça, Helena não é levada por Páris nem sequer pelos troianos. Em vez disso, ela foi sequestrada e levada para o Egipto onde em tranquila castidade espera Menelau. Todo o mito que justificou a guerra era falso; as armas de destruição maciça não estavam lá. A Grécia, é Euripedes quem o sugere, tinha sido ludibriada com um mito, uma mentira. Porque enviar pessoas para morrer pelo ouro de Tróia, nessa altura, ou pelo ouro líquido, de hoje, não é uma política popular: a guerra tem de se tornar mítica, e ser feita pela "honra", ou "amor" ou "democracia", na ponta de uma bomba inteligente.

Em Hécuba, Euripedes, pela boca do mensageiro Taltíbio, lança dúvidas sobre os deuses usados para justificar a guerra e a morte: "Que posso eu dizer, Zeus - que olhas pela humanidade / Ou que isso é uma ilusão vã, sem consequências? / Acreditamos haver uma casta de deuses / Quando é o acaso apenas que controla as coisas do homem" (apud Durant 1939: 406).

Tal como Euripedes, Pinter usa o mito para jogar contra o mito que no nosso mundo moderno é produzido pelos media, pela cultura "popular" e o poder crescente dos governos para manipular ambos. Festa de aniversário (The

\footnotetext{
2 Moses Hadas escreve neste sentido sobre a complexidade da personagem na tragédia grega de uma forma que geralmente se associa a Pinter: "Há sempre lugar para o debate e reflexão, uma vez que a tragédia grega nunca apresenta um herói branco contra um vilão preto... 0 espectáculo da virtude sempre triunfante apenas poderia corroborar a presunção: o espectáculo da virtude sem mácula deitada por terra seria apenas chocante, como Aristóteles refere" (1950: 75).
} 
Birthday Party) joga contra o mito gerado pelos meios de comunicação do emissário de espírito decidido que é enviado numa missão, apenas, como já vimos, para revelar Goldberg como, afinal, um seguidor apático. 0 regresso a casa destrói o mito da família muito unida. Ben e Gus são, num certo sentido, cavaleiros míticos que partem numa missão, só que, na versão de Pinter em 0 serviço (The Dumb Waiter), eles não compreendem isso, o que se torna auto-destrutivo. Traições (Betrayal) abala o mito do amor romântico que existe numa esfera separada das outras realidades, como a amizade entre homens, as crianças ou o trabalho. As palavras de Jerry, expressas de forma brilhante, aqui, na conclusão da peça, carregam na sua afirmação romântica absoluta toda a ironia do que se passou antes: "Estou loucamente apaixonado por ti. Não acredito que aquilo que alguém neste momento diga que aconteceu tenha alguma vez acontecido. Nunca nada aconteceu. Nada. Isto é a única coisa que alguma vez aconteceu" (Pinter 2002b: 166).

Mas o mito que é hoje mais relevante para nós, o que Pinter expõe, como o fez Euripedes nas suas peças políticas, é o do Estado todo-poderoso que se justifica a si próprio e que se considera imune a todas as outras leis em função do serviço que realiza sob o nome de patriotismo. Em Lingua da montanha (Mountain Language) ele faz isso, como Euripedes fez n' As troianas, ao mostrar o sofrimento dos que são destruídos pelo mito, recusando que permaneçam como abstraç̧ões. Em ambas as peças, as mulheres tremem pela família, por aquilo que foi e é agora destruido sem sentido. Ouçamos o lamento de Hécuba e o Coro:

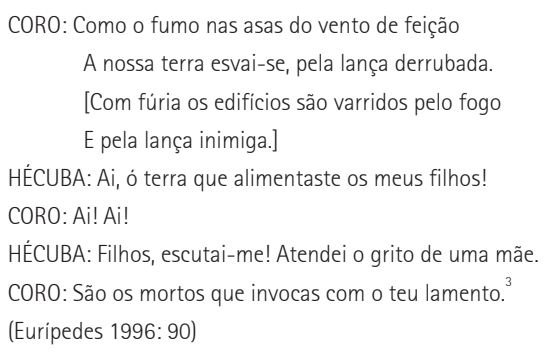

HÉCUBA: Ai, ó terra que alimentaste os meus filhos! CORO: Ai! Ai!

HÉCUBA: Filhos, escutai-me! Atendei o grito de uma mãe. CORO: São os mortos que invocas com o teu lamento. ${ }^{3}$ (Euripedes 1996: 90)

Em Língua da montanha, no meio de toda a brutalidade e uso arbitrário do poder pelo poder, o palco fica a meialuz e o nosso sentido do que se perde vem da Jovem e do seu marido prisioneiro, finda a voz, porque ela não pode nunca existir naquela realidade. Eles falam de uma realidade interior, de memória, de amor, com saudade do que humanamente existia, devia existir e, pela acção do Estado, não pode existir.

VOZ DO HOMEM: Estamos num lago.

VOZ DA JOVEM MULHER: É Primavera.

VOZ DO HOMEM: Abraço-te. Aqueço-te.

VOZ DA JOVEM MULHER: Quando os meus olhos se abrem, vejo-te sobre mim, a sorrir. (Pinter 2002b: 200)
Sentindo, porém, que pôr em cena o Estado com toda a sua parafernália, os seus uniformes, movimentos de massas, paradas e música poderia de facto reforçar o próprio mito que uma peça ou um filme podem querer criticar, como fizeram, por exemplo, tantos filmes sobre a Alemanha de Hitler, Pinter reduz o Estado militarista aos seus elementos mais simples: os torturadores, gente oca que tem de ser insuflada com o poder do Estado para ter alguma identidade, e os que se aproveitam disso para alegremente reprimirem toda a humanidade e assim manterem o seu estatuto. A imagem grande é exposta em formato pequeno, enquanto a crueldade, o sadismo e a volúpia do poder no Estado são vistos e desmistificados através da dramatização desse poder no individuo. Nas quatro cenas separadas de Um para o caminho (One for the Road), o que o torturador Nicolas explora é a vulnerabilidade daqueles que amamos, mesmo quando o Estado hoje impõe que se respeite o direito de cada um proteger os que ama. 0 poder da vida e da morte relativamente aos que amamos. É o mesmo, porque Nicolas está - e se identifica - com o poder, mitificado como patriotismo, que o Estado Ihe confere. E, como Pinter referiu em "A peça e a sua política", o público, dolorosamente, deve identificar-se com um tal poder:

No entanto, também é verdade que na peça se dá rédea solta a muitas das qualidades sádicas naturais, que todos nós possuimos. 0 público sentiu medo - mas era medo de quê? Medo não só de estar na posição daquela vítima, mas também um medo nascido de um reconhecimento de si próprio como interrogador. Senão, pensem no gozo que é ter um poder absoluto. (Pinter 2006: 191).

N' As bacantes, sob a influência da orgia báquica, as mulheres, o circulo interior por assim dizer, despedaçam o intruso, Penteu, que ousara olhar para as suas orgias. Para os espectadores gregos, que aceitavam o mito, Penteu é punido justamente por ter violado o seu retiro e caluniado as devotas de Baco. Mas os que conheciam as peças de Euripedes, devem ter tido outros pensamentos quando viam Agave, a mãe de Penteu, arrancar violentamente um dos seus ombros, espetar a sua cabeça no seu festão de hera, e correr triunfante para a cidade com o seu "troféu de caça" (Eurípedes 1992: 98), a pedir ao seu pai Cadmo: "Orgulha-te da minha caçada e convida para um festim os teus amigos (/bidem: 98). No início da peça, o coro tinha entoado uma purificação sobre os celebrantes: "Bemaventurado o ditoso / que conhece os mistérios divinos / purifica a sua vida" (Ibidem: 43).

Tanto em Tempo de festa (Party Time) como em Comemoração (Celebration), Pinter encena bacanais semelhantes para o nosso tempo. Os celebrantes também se divertem nos seus próprios mistérios, que lhes asseguram, pela graça de Deus, presume-se, o privilégio de ficarem limpos e santificados, unidos como estão num "bando sagrado" que, de igual forma, pune os forasteiros que ameaçam os seus privilégios. Mais uma vez, pelo facto de não localizar a situação num lugar ou tempo históricos 


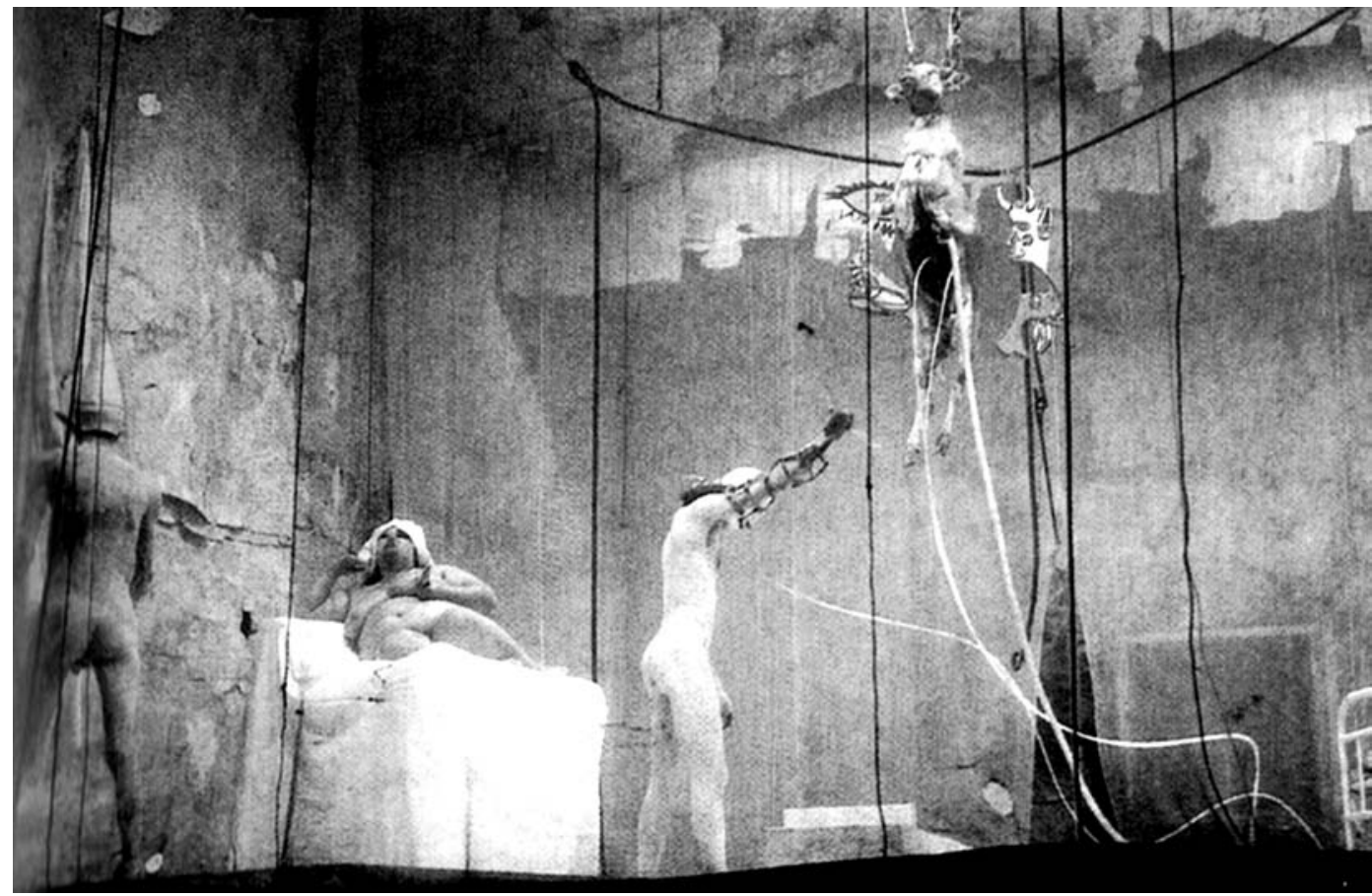

Oresteia

(Uma comédia orgânica?),

\section{de Ésquilo,}

enc. Romeo Castellucci, Societas Raffaello Sanzio 1995, fot. Luca Del Pia.

absolutos, Pinter faz eco de todos nós que preferimos não saber da dor do "outro" ou do custo para os "outros" de usarmos a maior parte dos recursos do mundo enquanto 30000 crianças morrem diariamente no mundo por causas ligadas à pobreza. Em Tempo de festa, Dusty põe em risco o clima de celebração pelo facto de se preocupar com o seu irmão que está fora quando um grupo de dissidentes é levado pela polícia. 0 seu marido, Terry, adverte-a:

Quando vens a uma festa encantadora como esta, tudo o que tens a fazer é estar calada, desfrutares da hospitalidade e só te preocupares com a porcaria da tua vida. Quantas mais vezes terei eu de te dizer isto? Continuas a ouvir todas essas coisas. Continuas a ouvir todas essas coisas espalhadas por uns bandalhos sobre outros bandalhos. 0 que é que isso tem a ver contigo? (Pinter 1993: 288, tm)

Mas Pinter expõe a violência no coração desta "paz de ferro". Tendo "decepcionado" o seu marido ao relacionarse com o "outro", que tinha sido marginalizado ao ponto de ser apodado de "espinho" ou, hoje, de "rebelde" e "terrorista". Dusty pergunta, ironicamente, se ele a matará: "Acredita que se conseguir eliminar-me conseguirá com isso eliminar tudo o resto para todos?" (Ibidem: 301-302) E, por um momento Terry delicia-se com uma fantasia sádica que pressagia a destruição universal:

Temos dezenas de opções. Podemos sufocar cada um de nós, basta um sinal nosso, ou podemos enfiar o cabo de uma vassoura pelo rabo acima de cada um de vocês, basta outro sinal, ou podemos ainda envenenar todo o leite materno no mundo, de modo a que todos os bebés caiam mortos antes de conseguirem abrir a porra das suas bocas pervertidas. (Ibidem: 302 )

As últimas palavras em Tempo de festa, todavia, são do outsider, do marginalizado, sempre presente à porta. Como oposto ao "rebelde" humilhado, ele insiste no nome: "Eu tinha um nome. Era Jimmy. As pesoas chamavam-me Jimmy. Esse era o meu nome" (/bidem: 313). Jimmy, o outsider à porta do nosso luxo, Jimmy o que pode ser dispensado, o morto que enviamos para a morte para que a nossa festa continue. Que imagem teatral absolutamente perfeita este final de Tempo de festa! Um ícone através dos tempos, o outsider à nossa porta, os mortos cuja morte não sentimos nem choramos, porque eles são "o outro". 0 meu nome era Hécuba. 0 meu nome é Paul. Eu era de Dahfar. As pessoas chamavam-me Paul. Esse era o meu nome. Através dos tempos, Pinter deixa-nos preencher o que está em branco.

N' As bacantes, como em Tempo de festa e noutras peças políticas de Pinter, então, os que se divertem perdem momentaneamente a sua identidade, e com ela a sua responsabilidade pessoal. Para Euripedes na orgia, para Pinter em todas as tarefas do Estado - nação que o desresponsabilizam. As suas vitimas também são ameaçadas com a perda da identidade - "espinho", "homem", "rebelde", "intruso". Nos dois exemplos, o momento trágico ocorre quando o nome é reafirmado e a vítima se torna outra vez humana, um de nós que destruímos, ou seja, quando o intruso se torna outra vez Penteu - filho, pai - destruído pela sua própria mãe e pelas crendices que não questionamos: "Tu vês, ó pai, como a minha vida mudou" (Euripedes 1992: 104). Como quando o "rebelde" se torna apenas num outro filho de uma qualquer mãe.

Assim também se passa com Jimmy que, como outsider, transporta consigo todas aquelas mortes, bem como a falta de visão e de compreensão que o público acabou de testemunhar na festa leviana dos privilegiados: "A escuridão está na minha boca e eu chupo-a. É a única coisa que tenho. É minha. Pertence-me. Chupo-a" (Pinter 1993: 314). E eu não posso deixar de pensar que o que Pinter disse sobre o público em A língua da montanha também é verdade aqui. Uma parte de nós envergonhase e sente-se desconfortável, porque, a um certo nivel, nós também nos identificamos com o poder e com o luxo.

Em Comemoração, algumas palavras de código unem o "nós" privilegiados, exactamente como continuam a identificar os outsiders. Diferentemente de Tempo de festa,
Na sua adaptação da peça, Jean-Paul Sartre deu as últimas palavras a Poseidon: "Agora ides pagar / Fazei a guerra, imortais imbecis, / devastai os campos e as cidades, / violai os templos e os túmulos, / torturai os vencidos / rebentareis também. / Todos" (1973: 110). 


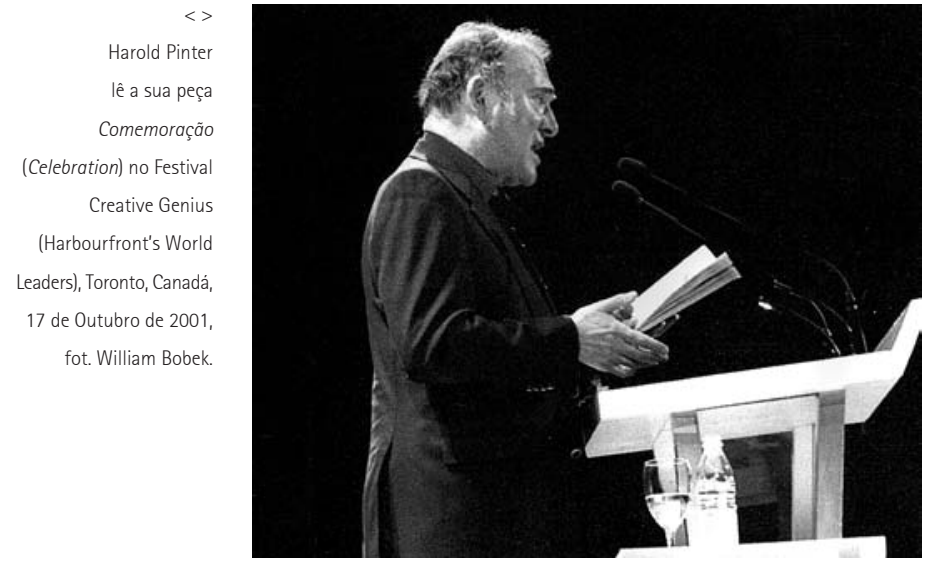

todavia, parece não haver aqui nenhuma ameaça exterior imediata, pelo que Pinter expõe a necessidade de uma constante e séria ameaça exterior, mesmo se em grande medida ela não exista, com o fim de manter e justificar os privilégios que estão ligados ao poder: "A liderar. A manter a paz. A reforçar a paz" (Pinter 2002b: 251). Para prosseguir na ligação com Euripedes, precisamos sempre de um Penteu para esquartejar, para que a celebração continue, e a finalidade real do mito é destruir o tempo real e a história real até que, no clímax da orgia, nada mais resta do que o "nós" e "eles", "nós" e, tristemente, uma palavra tão antiga como a história: "o nosso inimigo". No momento em que Agave despedaça o seu filho, não há nenhuma história real, passada ou futura, há apenas a história mítica - inventada - do momento que justifica o acto, mesmo quando hoje distorcemos as cores de uma ameaça e convertemos uma ameaça real, mas relativamente menor, numa oposição binária que tudo abrange e tudo justifica. Mas mesmo na claustrofóbica Comemoração, a história é o presente embora se revele ineficaz nas interjeições do criado. Porque as metáforas da peça relativas a incesto, útero, claustrofobia, não são apenas um comentário irónico à frivolidade da celebração, mas definem a sua insularidade. Só o criado, quando todos os outros saíram, fica sozinho a comentar indirectamente a nossa situação histórica real: "Não consigo encontrar a porta de saida" (Ibidem: 256).

Ao discutir o teatro de Harold Pinter e o teatro trágico grego, espero ter chamado a atenção para a profunda humanidade da obra do dramaturgo inglês. Ambos avaliam o nosso lugar humano no mundo. Ambos nos acusam quando, enquanto individuos ou Estados, inchamos com arrogância ou orgulho, e ambos vêem essa hybris como essencialmente destrutiva. Ambos exigem que nos identifiquemos com a humanidade no seu todo que, como nós, nasce e morre, uma humanidade comum que se estende para lá dos Estados, dos géneros e, com toda a certeza, das ideologias. Muito se tem escrito ultimamente sobre o Pinter "zangado", mas essa ira, acredito firmemente, como especialmente a de Eurípedes, nasce do desânimo perante a nossa capacidade de auto-ilusão e da negação da nossa humanidade comum. Nasce então, em última análise, do amor. Obviamente, como referi no início, há muitas diferenças no tempo, nas realidades para que aponta a linguagem, talvez também na catharsis. Mas parece-me claro, como espero ter mostrado, que os tragediógrafos gregos, tal como o seu público, reconheceriam Harold Pinter como um dos seus, por uma

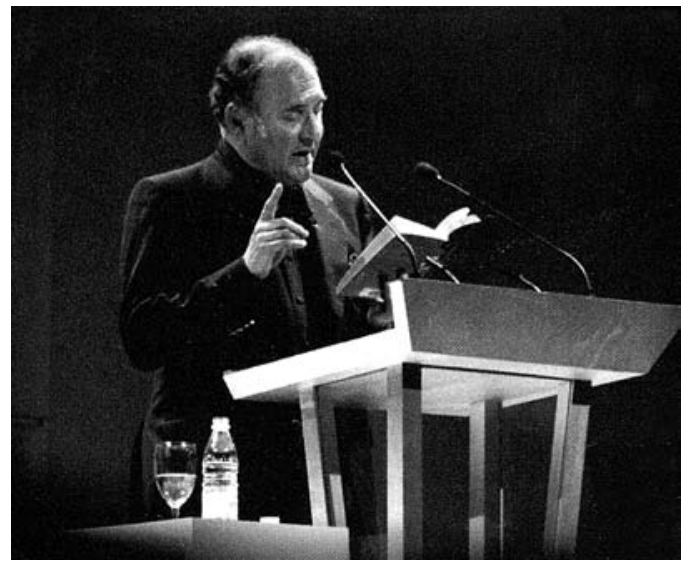

afinidade de espirito. Com justiça Harold Pinter ocupa o seu lugar não apenas junto dos maiores dramaturgos do nosso tempo, mas dos de todos os tempos.

\section{Referências bibliográficas}

ÉSQUILO (1975), Agamemnon, in Teatro completo, trad. Virgílio Martinho, Lisboa, Editorial Estampa.

BATTY, Mark (2001), Harold Pinter, Devon, Northcote House

DUKORE, Bernard F. (1976), Where Laughter Stops: Pinter's Tragicomedy, Columbia and London, University of Missouri Press.

DURANT, Will (1939), The Life of Greece, New York, Simon and Schuster. EURIPIDES (1992), As bacantes, trad. Maria Helena da Rocha Pereira, Lisboa, Edições 70.

- - (1996) As troianas, trad. Maria Helena da Rocha Pereira, Lisboa, Edições 70

HADAS, Moses (1950), A History of Greek Literature, New York \& London, Columbia University Press.

KITTO, H. D. F. (1963), The Greeks, Harmondsworth, Penguin

MURRAY, Gilbert (1966), A History of Ancient Greek Literature, New York, Frederick Ungar.

PINTER, Harold (1993), Party Time, in Plays Four, London, Faber and Faber, pp. 279-314.

- - (2002a), Teatro I [O quarto, A colecção, 0 amante, 0 regresso a casa, trad. Pedro Marques; Feliz aniversário, trad. Artur Ramos e Jaime Salazar Sampaio; 0 serviço, trad. Pedro Marques e João Saboga; 0 encarregado, trad. Francisco Frazão], Lisboa, Relógio d'Água.

- - (2002b), Teatro II [Paisagem, Há tanto tempo, Victoria Station, trad. Jorge Silva Melo; Monólogo, trad. Luis Fonseca; Terra de ninguém, trad. Francisco Luis Parreira e Alcides Estrela; Traições, trad. Berta Correira Ribeiro; Um para o caminho, Conferência de imprensa, trad. Pedro Marques; Lingua da montanha, A nova ordem mundial, Cinza às cinzas, Noite, trad. Paulo Eduardo Carvalho; Comemoração, trad. José Maria Vieira Mendes; A Black and White, É só isso, trad. Francisco Frazão ; Candidato, trad. Graça P. Corrêa], Lisboa, Relógio d'Água.

- - (2006), Várias vozes, trad. Miguel Castro Caldas, João Paulo Esteves da Silva, Jorge Silva Melo, Francisco Frazão, Pedro Marques, Joana Frazão, Vila Nova de Famalicão, Edições Quasi, pp. 185-195.

SARTRE, Jean Paul (1973), As troianas, trad. Helena Cidade Moura, Lisboa, Plátano Editora, Colecção Teatro vivo.

SÓFOCLES (2003), Antigona, trad. Maria Helena da Rocha Pereira, in Tragédias, pref. Maria do Céu Fialho, introd. e trad. Maria Helena da Rocha Pereira, José Ribeiro Ferreira, Maria do Céu Fialho, Coimbra, Minerva. 